\title{
The Impact of Conservancy Fragmentation on the Population Distribution and Feeding Patterns of Roan Antelope 2000-2009: The Case of Chiredzi River Conservancy
}

\author{
Munzanza Dickson \\ Chikwirire Secondary School, Zimbabwe
}

Copyright $(2016$ by authors, all rights reserved. Authors agree that this article remains permanently open access under the terms of the Creative Commons Attribution License 4.0 International License

\begin{abstract}
The Zimbabwe's fast track land reform programme caused among other thing significant conservancy fragmentation which led to serious changes in wildlife distribution and their feeding patterns. This study sought to investigate the impact of conservancy fragmentation on the population distribution and feeding patterns of the Roan antelope (hippotragus simum) in Chiredzi river conservancy of Chiredzi north district. Observations were only carried out by the researcher on the state of the conservancy and feeding habits of roan antelope. The capture and recapture technique in this research was employed to select the species sample that were systematically chosen. The stratified systematic sampling was used to minimise bias in selection as well as to determine the point locations where the Roan Antelopes were to be captured. The species were captured using the trapping net in which the species were driven into the net. This method was environmentally safe in that life was valued because injuries of species during the capturing process were avoided. Four captured Roan Antelopes were fitted with the collar coding system, where the calcium detector was used for remote sensing. This helped in easy tracking and identification during observation and surveying. The observation and tracking process consume twelve months since they observed in four different season of the year. This plays a critical role in analysing the state of feeding area as well as captive breeding area. Field measurements were done on the observed roan antelope and the carrying capacity of the conservancy. The research findings revealed that as from 2000 to 2009 the population of Roan Antelope declined by almost $83 \%$. It is concluded that it is very important to implement appropriate conservancy management strategies for wildlife especially for Roan Antelope. It is therefore recommended that there should be the introduction of intensive protected zone (I P $\mathrm{Z}$ ) in order to restore the population of the Roan Antelope
\end{abstract}

in the Chiredzi River Conservancy.

Keywords Conservancy Fragmentation, Population Distribution and Feeding Patterns, Environmental Bearing Capacity

\section{Background to the Study}

Management of wildlife started in the early 18 th century when, more than a million flora and fauna species were at high risk of extinction. This was as a result of 17 th century's industrial revolution that intensively ravaged the flora and fauna across the globe (Spinage 1986). The situation attracted global attention towards conservation and preservation of wild resources forcing creation of national parks, private parks and zoos. The major concern was to protect and preserve species which were at the edge of extinction. According to IUCN SSC Antelope specialist group (2008), globally approximately 65000 flora and fauna species get extinct on yearly basis as from the early 1970 s.

Moyo (2000) defines fragmentation as a disruption of extensive habitat into isolated and small patches. The factors that contribute towards conservancy fragmentation are global population pressure, political instability and economic recession caused global conservancy fragmentation. Social and political instability have contributed to the subdivision of the Amazon basin in Brazil, national resources in Tanzania during the Ujama resettlement scheme and the conversion of $30 \%$ of the total area of Botswana game reserve to sugar cane plantation in the early 1990s (Whitmore.et al 1992 and Koewals ,2000). African hunting adventures, (2001) and Moyo,(2000) stated that between 2000 to 2009 ,Zimbabwe experienced the 
fragmentation of major conservancies ,game parks ,plantations, farms According to Wildlife Africa (2001), 8,7\% of Gonarezhou was distributed to the Chitsa tribe, Tshovane tribe ,Midlands black rhino conservancy ,Save valley conservancy, Chiredzi river as well as Hwange national game reserve . Chenje (2000) pointed out that, this fuelled poaching, rapid cutting down of vegetation for land clearing. African hunting adventures, (2001), cited that wildlife production was reduced by almost $65 \%$ in Zimbabwe.

\section{History of Roan Antelope}

In the conservancy the antelope is one of the most successful species. The species has more than 30 sub specie which is also found in the region (Southern Africa). Benedetti et al (2001) investigated that among the subspecies, the sable antelope is the largest and most successful with a growth rate of 1.4 per year. Roan Antelope is the second successful subspecies and it is under reintroduction with maximum conservation measures being put in many parts of southern Africa (Guisto at el 2001).According to African hunting adventures (2001), Roan Antelope is listed in the red list of IUCN and in appendix ii of CITES.

Roan antelope (hippotragus simum) is of vital importance for nutrient cycling in the savannah ecosystem in which it lives. It serves as an important prey species for its predators (lion, cheetah).In Zimbabwe especially in the study area it attracted eco-tourism activities and trophy hunting as a result of its unique horns and shining coat. The species also has hides of high economic value, useful for belts, handbag, shoes and coat making. However Roan Antelope provides marketable bush meat (African hunting adventurers, 2001).

\section{Problem Statement}

Despite conservation measures being applied in Roan Antelope (hippotragus simum) protection by the IUCN, Chiredzi river conservancy is now facing serious problems that led to conservancy fragmentation as a result of agricultural cropping activities encroachment. Massive destruction of biodiversity in the conservancy jeopardizing food management for wildlife. Parallel management of the conservancy becomes a second solid challenge in the industry. The tension rose between rural district council, Parks and wildlife department and the conservancy management board over which organisation deals with the allocation and approval of quatos.

Drastic change in land tenure and security caused wildlife habitats in Chiredzi river conservancy to be put under tremendous pressure (Moyo, 2000). Massive translocation and out migration of Roan Antelope to other areas become one of the outstanding problem contributing to extinction of the species in the study area. Heavy poaching and habitat encroachment became the day to day problem affecting the business of wildlife management in the conservancy which demands immediate practical mitigation measures.
Therefore the central focus of this study is to make an investigation on the impact of conservancy fragmentation on the population distribution and feeding patterns of Roan Antelope in chiredzi river conservancy in chiredzi north district.

\section{Objectives}

General objective

To investigate the impact of conservancy (habitat) fragmentation on thepopulation distribution and feeding habits of roan antelope (hippotragus simum).

Specific objectives

1. To assess changes in population distribution and feeding patterns of the roan antelope (hippotragus simum) in the Chiredzi river conservancy.

2. To analyse the effects on the changes in population distribution and feeding patterns of roan antelope (hippotragus simum) in the Chiredzi river conservancy.

3. To evaluate the current conservation and protection strategies for roan antelope (hippotragus simum) in the area

\section{Hypothesis}

Null hypotheses

H0 There is no significant relationship between forage quality and species rephus.

H0 There is no relationship between physiological characteristics and BMR.

\section{The rationale of the study to the cooperate world}

Due to increased habitat loss and the subsequent decline in the roan antelope (hippotragus simum) along with failing attempts to curb unnecessary destruction of vegetation and poaching in Zimbabwe and the whole of Southern Africa, the research outcome shall help in several ways:

The outcome will inform governmentthe cooperate world to join hands together to look into wildlife welfare. and as well as on policy formulation and decision making about the protection of roan antelope (hippotragus simum).

Suggestions and recommendations from this research shall be useful to the Ministry of Environment and Tourism on the appropriate actions to be taken pertaining to protection of roan antelope (hippotragus simum) which is currently under threat of extinction in Zimbabwe.

The research outcomes shall also inform Chiredzi river conservancy and other conservancies on the way forward on wildlife food management, strategies likely to solve the problems and improvements to be made in the conservancy. The research also aims to play a major role towards the attainment of this objective, thus the ruthless exploitation of the earth capital because the resilience of the ecosystem is limited and the danger point has already been reached.

Lastly the study will also act as a basis or provide grounding for other coming studies. 


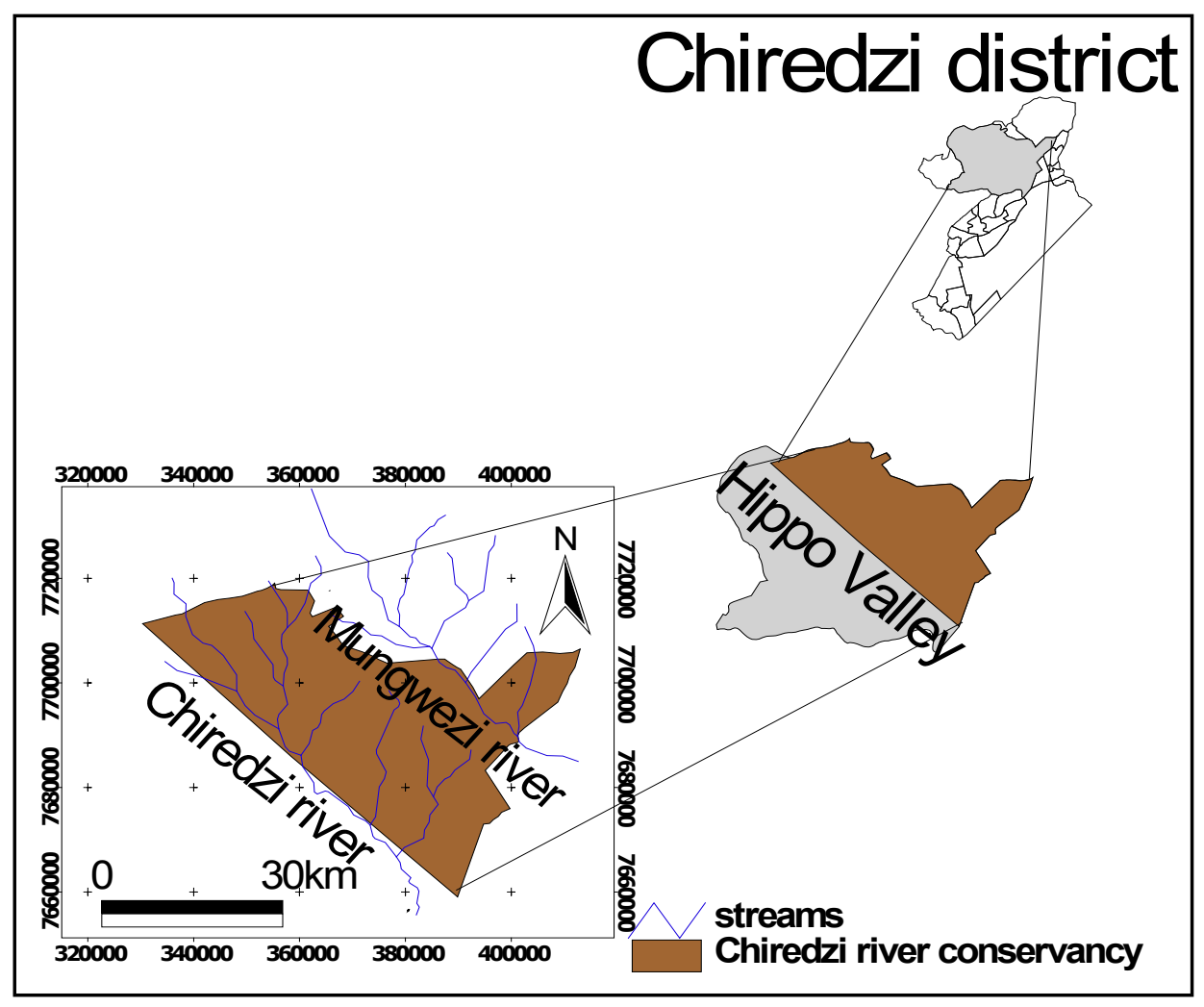

Figure 1.1. Map of Chiredzi river conservancy

\section{Location}

Chiredzi river conservancy is located in Chiredzi North district of Masvingo province. The conservancy consisting of privately owned estates. The conservancy is dissected by two major rivers. These rivers include Chiredzi River found to the far east of the conservancy and Mungwezi River to the central western side of the conservancy. They drain from the North West to the south east. The conservancy stretches from the north where it demarcates Zaka and Chiredzi districts to the south.

\section{Physical characteristics}

Chiredzi river conservancy is located in natural region 5 . The area receives erratic rainfall of less than or equal to 250 $\mathrm{mm}$ per annum and with temperatures that ranges from 25degrees Celsius to 27.5 degrees Celsius (Chenje 1998). It also record temperatures that may be higher up to 40degrees Celsius in October and in mid January. However, the temperatures can drop to 9degrees Celsius in early June to mid July. Meanwhile November to mid December will be the wettest months that receive $70 \%$ of the total rainfall received in the area per rain season (Peterson, 1991).

Chiredzi River Conservancy covers a total area of 89482 hectares. The conservancy is situated 500 meters above sea level and found $21^{0}, 20^{1}$ latitude and $30^{0}, 27^{1}$ longitudes. The soils that forms $89 \%$ in this area are known as regosol .Regosol are deep medium grained sands with poor horizonation. The central belt of the conservancy consists of soils derived from basalt. Basalt are black clays which are sticky when wet and crack when dry(Nyamapfene 1991). The conservancy is dotted with good salt pans all over but mainly the western side. The study area consists of good and highly palatable grasses species aristida, dactyloctenium,panicum,brachiaria and digitaria. Tree specie Brachestiga species, compretum Mopani, strychnos ssp, and acacia dominated $65 \%$ of the conservancy.

\section{Assumption of the Study}

The researcher made the following assumption.

1. A habitat characteristic controls the population distribution and feeding patterns of roan antelope.

2. Habitat fragmentation affect the population distribution of roan antelope

3. Feeding habits significantly correlates to the physiology of roan antelope.

\section{Methods and Materials}

\section{Research Design}

Research design is an analytical plan for selecting subjects' research instruments that are employed for data collection, enhancing clear data analysis, which answers research objectives (Tuli, 1993). In this particular research qualitative and quantitative research designs were used.

Qualitative Research Design 
In this research the researcher employed in-depth interviews, direct observation, and written documents. The information which were given out by qualitative research methods include physical feeding patterns of the Roan Antelope being made possible with the use of direct observation, management strategies employed currently for the Roan Antelope, documentary feeding habits of the Roan Antelope in the conservancy as well as the bio-physiology demography of the species.

Quantitative Research Design

Employed to collect data that critically shows a significant shortfall of required nutrients needed for a normal growth of a species. Variables are experimentally tested and values are statistically tested to find level of significance. Variables that are measured and tested in this research include dental description; mass and height. These variables are important in determining the general physiological body growth of the species under investigation. Hay analysis as one of the variables of interest is so essential to be examined as it helping in depicting the state of forage in the conservancy. Population and reproductive rate were tested and examined.

\section{Population and Sampling Procedure}

In this study ten Roan Antelope were selected using stratified systematic sampling so as to avoid bias in species selection and as a result the selected species will represent a true picture of the species found in the conservancy. Chairman of the conservancy, Parks and Wildlife Officer, Chiredzi Rural District Chief Executive Officer, ecologist and ranger were selected for further investigation and were chosen using the convenience sampling. This sampling technique saves time and allowed the researcher to gather information from the most appropriate respondents targeted.

Methods and materials for data collection

\section{Observation}

The observation was done for twelve months that started from the commencement of the project right up to the end of the study. Information observed would be recorded by making use of observational diaries. Information of interest observed includes sex, herd size, grid location, orphans, palatable grass and trees species and finally carcasses observed. The researcher would be constrained by not being able to observe other roan antelopes in some of the paddocks regarded as restrictive areas.

In completing the data sheet the observer used grid numbers to show the area where the species were observed. Answers were given as 0 when no occurrence was observed and actual values $(1,2,3 \ldots \mathrm{n})$ when an occurrence observed. Under the column for carcasses, the number observed and causes for death were represented with numerical values and letters used respectively, $\mathrm{N}$ for natural causes, $\mathrm{P}$ for poaching and $\mathrm{U}$ for unknown.

\section{Field Measurements}

The Field measurements were carried out within the study area. ten captured Roan Antelopes were fitted according to the collar coding system. Their weight, height and dental characteristics were measured for physiological determination.Their movement and fate were closely monitored once per month in a period of twelve months. Monitoring took place within a time space of 4 months so as to allow sufficient mixing of the species which will help the researcher in estimating the population of the Roan Antelope species. After recapturing their weight, height and dental characteristics were re- measured and analysed.

Examination of general species physiology

Determination of teeth eruption

Nomenclature deciduous teeth and permanent teeth examined.

Table 3.1. Field observation patrol data sheet

FIELD OBSERVATION PATROL DATA SHEET

RECORDER.

SPECIES BEING MONITORED.

\begin{tabular}{|c|c|c|c|c|c|c|c|}
\hline $\begin{array}{c}\text { GRID } \\
\text { NUMBER }\end{array}$ & $\begin{array}{l}\text { INDIVIDUAL } \\
\text { PER HERD } \\
\text { SIGHTED }\end{array}$ & $\begin{array}{l}\text { NUMBER } \\
\text { OF } \\
\text { ORPHANS }\end{array}$ & $\begin{array}{c}\text { NUMBER } \\
\text { OF CARCASSES }\end{array}$ & $\begin{array}{l}\text { CAUSE(S) } \\
\text { OF DEATH }\end{array}$ & $\begin{array}{l}\text { GRASS/ } \\
\text { TREE } \\
\text { SPECIES } \\
\end{array}$ & SEX & DATES \\
\hline & & & & & & & \\
\hline & & & & & & & \\
\hline & & & & & & & \\
\hline
\end{tabular}




\section{Examination of old skull in determination of species teeth eruption stage}

In preparing the specimen on an old skull carcass, the gum line can often be determined by the line of staining on the teeth useful in estimating the age at which the species died. necessary steps

Step 1: The skull boiled in water at 125 degrees cecius

Step 2: Two handfuls of sodium per borate powder added in boiling water and left for 15 minutes so as to clean and bleach the specimen for easy recognition of ridges on the teeth and level of eruption.

\section{Examination of teeth eruption of captured species}

The following is the characteristics of a full set of teeth formula employed by the researcher in analysing teeth eruption stage: $2(\mathbf{i}[\mathbf{0} / 3]$ c [0/1] pm [3/2] m [3/3]), whereby i- Incisor, c- canines, $\mathbf{p m}$ - premolars and m-molars

Step 1: The captured species were injected with tranquilizers

Step2: The mouths of each of the species were then widened for clear teeth examination. The procedure took almost 2-3 hours for each of the individual species to get the required information. The data obtained was recorded in the collection data sheet like the one below.

Table 3.2. The deciduous teeth formula employed in dental analysis for this particular research:

\begin{tabular}{|c|c|c|c|c|c|c|c|c|}
\hline description & \multicolumn{3}{|c|}{ I } & \multicolumn{1}{c|}{ C } & \multicolumn{4}{c|}{ PM } \\
\hline \#of teeth & 1 & 2 & 3 & & 1 & 2 & 3 & 4 \\
\hline UPPER & & & & & & & & \\
\hline LOWER & & & & & & & & \\
\hline
\end{tabular}

Table 3.3. The permanent teeth formula employed in dental analysis for this particular research

\begin{tabular}{|c|c|c|c|c|c|c|c|c|c|c|c|}
\hline Description & \multicolumn{3}{|c|}{ I } & C & \multicolumn{5}{c|}{ PM } & \multicolumn{3}{|c|}{ M } \\
\hline \#of teeth & 1 & 2 & 3 & 1 & 1 & 2 & 3 & 4 & 1 & 2 & 3 \\
\hline UPPER & & & & & & & & & & & \\
\hline LOWER & & & & & & & & & & & \\
\hline
\end{tabular}

\section{Calculation of Height}

Height, is the vertical standing distance measured from the shoulder to the hooves. The distance measured using a clinical measuring tape.

\section{Calculation of weight}

In this particular research weight was derived from the breast chest width through calibrating the results into kilograms using the calibration table.

\section{Measurement of horn size}

Horn size was measured using a photogrammetric device mounted on a $300 \mathrm{~mm}$ lens. This device determines the distance between the camera and the object being photographed, allowing measurements to be obtained from photographs with 99\% accuracy.The information pertaining to weight, height, horn size and dental characteristics was recorded in the field patrol data sheet in appendix B.

Determination of roan antelope population in the study area.

\section{Calculation for general population estimation of Roan Antelope}

The population of the roan antelope species was determined by using the Lincoln index. The index is calculated as follows:

$$
\begin{gathered}
\text { Total population }=\frac{\text { \# of organisms in initial sample } \times \text { of organisms in second sample }}{\text { \# of marked organisms recaptured }} \\
\begin{array}{c}
\mathrm{T}=\frac{\mathrm{X}_{1} \times \mathrm{X}_{2}}{\mathrm{Y}} \\
\frac{\mathrm{X}_{1} \times \mathrm{X}_{2 \times 100}}{\mathrm{Y}} \\
\mathbf{x y} \%
\end{array}
\end{gathered}
$$

\section{Calculation for population viability analysis of Roan Antelope}

This was done mathematically using the formula below:

$$
\begin{gathered}
\mathbf{r}=\frac{\left(\ln \left(\mathrm{N}_{0}\right)-\ln \left(\mathrm{N}_{\mathrm{t}}\right)\right)}{\mathbf{t}} \\
\mathbf{N}_{\mathrm{t}}=\mathrm{No}_{\mathrm{e}}{ }^{\mathrm{rt}}
\end{gathered}
$$

Source: (Lenore, 2009),

Where:

$\mathbf{r}$ is the difference in the size of the population at two censuses divided by the time interval between the censuses. The formula's parameters were biologically tested true and described as the Malthusians parameters.

$\mathbf{N}_{\mathbf{0}}$ is population at initial survey

$\mathbf{N}_{\mathbf{t}}$ is the population observed at time $\boldsymbol{t}$ 
The conditions when $r=0$ shows that the population is stable, $r \leq 0$ clearly shows that the population is declining and when $r \geq 0$ if the population is increasing. Then therefore $r$ is the actual rate of growth of the population

\section{Calculation for growth rate (species population variation) in relation to food availability}

Population growth is usually density dependent modelled by the following logistic equation below:

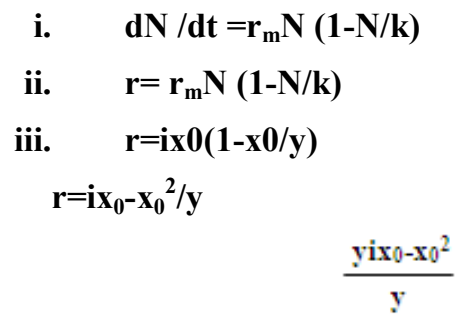

$\mathbf{d N} / \mathbf{d t}$ is the instantaneous growth rate of the population

$\mathbf{K}$ is the carrying capacity of the study area

$\mathbf{N}$ is a known initial population size of the species under investigation

$\mathbf{r}_{\mathbf{m}}$ is a species-typical intrinsic rate of population increases.

Source: (Michael et al, 2008)

\section{Calculation for life expectancy of the Roan antelope}

The Extinction model was used to calculate the life expectancy of the Roan Antelope species. The results were obtained through employing the following formula

$$
\begin{gathered}
\mathrm{T}=\sum^{\mathrm{Nm}} \sum^{\mathrm{Nm}} \mathrm{z} / \mathbf{y}\left(\mathbf{y}^{\mathrm{v}-\mathrm{r}) \mathrm{y}}-\mathbf{1} / \prod\left(\mathrm{z}^{\mathrm{v}+\mathrm{r})} /\left(\mathrm{z}^{\mathrm{v}-\mathrm{r})}\right.\right.\right. \\
\mathrm{x}=\mathrm{y} \quad \mathrm{z}=\mathrm{y} \\
\mathbf{T}=\mathbf{2} / \mathrm{v}-\mathbf{r}) \ln \mathbf{N}_{\mathrm{m}} \\
\mathrm{T}=\frac{\mathbf{2}_{\mathrm{m}}^{\mathrm{N}}}{\mathrm{V}-\mathrm{r}}
\end{gathered}
$$

Where:

T- Time expected for a population of a given size to become extinct

r- The population's maximum size which will call the population ceiling

$\mathrm{V}$-the variance of $\mathrm{R}$ attributed to environmental fluctuation

П- algebraic parameter

Further more, the species extinction rate observed only when $\mathrm{V}>\mathbf{2 r a n d}$ also when $\mathbf{V}<\mathbf{2 r}$ showed that the population is moving towards their carrying capacity. More so if the variables are as follows $\mathrm{V}=2 \mathrm{r}$ implies that the population is in a position to reach their maximum life expectancy.

Source: (Michael et al, 2008)

Determination of the forage quality in the conservancy

The researcher used the proximate analysis to analyse the nutritional content of the feed. The feeds were divided into six fractions which are moisture, ash, crude protein, crude fibre, ether extract (organic acids contained in plant leaves pigments) and nitrogen free extractions. The analysis was carried out at Malilangwe laboratories. Apparatus used include scale, sulphuric acid, sodium hydroxide, burner, beaker, muffle furnace, $1 \mathrm{~kg}$ of digested sample and the boric acid

\section{Nitrogen free extractions (NFE)}

This fraction consists of compounds such as the water soluble vitamins and any other feed component that has not been accounted for. It principally comprises of starch and sugar. It often constitutes the greatest proportion of the feed which therefore makes it a crucially important feed fraction.NFE is so essential for energy giving in animals. It is calculated using the following equation:

$$
\mathrm{NFE}(\mathrm{g} / \mathrm{kg})=1000-(\mathrm{ASH}+\mathrm{CF}+\mathrm{EE}+\mathrm{CP})
$$

Where $\mathbf{C P}$ - crude protein,

CF -crude fibre

NFE-nitrogen free extract

\section{Crude protein}

It is the amount of protein in a feed sample. Protein is a complex organic compound contains carbon, hydrogen, oxygen and nitrogen converted into fat and carbohydrates by animal cell. It is composed of two polypeptide chains held together by disulphide bridges. Protein estimated with the amount of nitrogen in the feed consists $50 \%$ of total dry mass of hay. It is expressed in $\mathrm{g} / \mathrm{kg}$ of hay. The procedures for estimating crude protein are as follows:

Step 1: digested sample were put in sulphuric acid $\left(\mathrm{H}_{2} \mathrm{SO}_{4}\right)$ for 15 minutes

$\mathrm{H}_{2} \mathrm{SO}_{4}$ converted all nitrogen present in the feed sample into ammonia $\left(\mathrm{NH}_{2}\right)$ and only nitrogen from nitrates converted into ammonia $\left(\mathrm{NH}_{2}\right)$ and nitrogen from nitrites is not easily converted.

Step 2: sodium hydroxide is then added to the sample for 10 minutes.

This was done as to liberate the ammonia $\left(\mathrm{NH}_{2}\right)$ in the feed sample. This helps to distil the ammonia $\mathrm{NH}_{2}$ into standard boric acid

Step 3: the extracted boric acid is titrated till the concentration was normalising. The volume obtained was measured in moles and expressed into percentage using standard expression to come up with the volume of nitrogen.

In estimating crude protein some assumptions are put forward:

- All nitrogen present is from the crude protein

- Nitrogen is derived from protein which contains $16 \%$ nitrogen so the nitrogen is multiplied by $6.25(100 / 16)$ for easy conversion of the findings into moles

\section{Ether extract}

This fraction contains lipids (lipoproteins), organic acids, alcohol and pigments. Ether extract is obtained through the following procedure

Step 1: first hydrolysing the digested sample with sulphuric acid for 10 minutes. 
Step 2: Feed sample was then subjected to continuous extraction with petroleum ether till the reaction normalises. The residual obtained is known as acid ether extract $(\mathrm{g} / \mathrm{kg})$.

\section{Crude fibre}

This fraction measures the indigestible components and bulkiness of the food. It is obtained as a residual after successive boiling of the material in $0.26 \mathrm{~N} / 0.23 \mathrm{~N}$ sulphuric acid $\left(\mathrm{H}_{2} \mathrm{SO}_{4}\right)$.

Step 1: A sample put in a 120 degrees Celsius boiling of 0.26 Nsulphuric acid for 25 minutes.

Step 2: the residue again put into $0.23 \mathrm{~N}$ sulphuric acids for 15 minutes. This was done to allow for further digestion of the cellulose till the required fibre is obtained.

Step 3: The residual brought out of the beaker and weighed and expressed in $\mathrm{g} / \mathrm{kg}$.

\section{Ash}

The ash content was determined by drying the ash of the sample at $550^{\circ} \mathrm{C}$ in a muffle furnace until all the carbon has been removed. The mass of the ash is then measured and expressed as $\mathrm{g} / \mathrm{kg}$ of the hay.

Source: (Annual Review of Ecology, Evolution and systematic, 2003)

Calculation for energy requirements estimation in Roan Antelope

The estimation was roughly drawn by the following mathematical formula which was biologically tested

$$
\mathrm{BMR}=70 \times \mathrm{W} \mathrm{W}^{3 / 4}
$$

total bmr estimation of a species of (w) $\mathrm{kg}$

$$
\mathrm{BMR}=70 \mathrm{~W}^{3 / 4} \mathrm{KJ}
$$

- BMR is basal metabolic rate that is the energy consumed per day while at complete rest measured in kilocalories

- $\mathbf{W}$ is the body mass

- 70 and $3 / 4$ are biological tested constants

Calculation for significance of variations in feeding habits and physiological characteristics

The Pearson's product moment( $\mathrm{r}$ ) of correlation co-efficient employed.

$$
r=\frac{n(\Sigma x y)-\Sigma x \Sigma y}{\sqrt{\left(n \Sigma x^{2}-(\Sigma x)^{2}\right)\left(n \Sigma y^{2}(\Sigma y)^{2}\right)}}
$$

Table 3.4. Pearson's product moment data content table on the forage quality and rephus.

\begin{tabular}{|c|c|c|c|c|}
\hline $\begin{array}{c}\text { Forage } \\
\text { quality(x) }\end{array}$ & Rephus(y) & $\mathrm{Xy}$ & $\mathrm{x} 2$ & $\mathrm{y} 2$ \\
\hline$\underline{\mathrm{Xo}}$ & $\mathrm{y} 0$ & $\mathrm{x}_{0} \mathrm{y}_{\mathrm{o}}$ & $\underline{\mathrm{x}}_{0}{ }^{2}$ & $\mathrm{y}_{0}{ }^{2}$ \\
\hline$\underline{\mathrm{x} 1}$ & $\mathrm{y} 1$ & $\mathrm{x}^{1} \mathrm{y}^{1}$ & $\mathrm{x}_{1}{ }^{2}$ & $\mathrm{y}_{1}{ }^{2}$ \\
\hline$\underline{\mathrm{x} 2}$ & $\mathrm{y} 2$ & $\underline{\mathrm{x} 2 \mathrm{y} 2}$ & $\mathrm{x}_{2}{ }^{2}$ & $\underline{\mathrm{y}}_{\underline{2}}{ }^{2}$ \\
\hline$\Sigma \mathrm{x}$ & $\Sigma \mathrm{y}$ & $\Sigma \mathrm{xy}$ & $\Sigma \mathrm{x} 2$ & $\Sigma \mathrm{y} 2$ \\
\hline
\end{tabular}

$$
\mathbf{r}=\frac{\mathbf{n}(\mathbf{x y})}{\sqrt{\left(\mathbf{n}(\mathbf{x y})^{2}\right.}}
$$

$\mathrm{r}=1$ (shows there is strong correlation relation)

$\mathrm{r} \geq 0$ (shows there is no correlation relation between the variables tested.)

\section{Interviews}

In this research, the researcher employed the interview to exhume information on the feeding habits of Roan Antelope before 2000 fast track land reform programme and that necessary for evaluating the conservation and protection strategies being employed in the management of Roan Antelope.

\section{Secondary Data}

The researcher gathered the information through the use of text books, journals and telegraphs in this research.

\section{Data Analysis Plan}

Data was analysed through statistical means and descriptive reports. The data in this particular research was presented in the form of tables, line graphs, , and bar graphs and in narrative reports.

\section{Data Presentation, Analysis and Discussion}

\section{Written Documents, Interviews and Observation Data Presentation}

\begin{tabular}{|c|c|c|}
\hline Ranch & Owner & Area(hectare) \\
\hline Spear grass & C.Holden & 1808 \\
\hline Nyamadingidza & C.Holden & 1866 \\
\hline Melrose & A Davies and D.Nesbit & 1816 \\
\hline Glen-devon & G. Southwood & 1825 \\
\hline Dawlish & D.Nesbit & 5678 \\
\hline Sebanani & B.Van Aarde & 3655 \\
\hline Oscro & T. Sarpo & 3010 \\
\hline $\begin{array}{c}\text { Chiredzi ranch south } \\
\text { lot } 2 \\
\end{array}$ & $\begin{array}{c}\text { I Rukatya(leased by } \\
\text { T.Sarpo) }\end{array}$ & 5104 \\
\hline Mungwezi & T. Balance & 5038 \\
\hline Crown ranch east & $\begin{array}{l}\text { Hein family(leased by } \\
\text { Dombodema ranching) }\end{array}$ & 9307 \\
\hline Buffalo range & Style family & 17000 \\
\hline Ruware & Ade la Rue & 33375 \\
\hline \multicolumn{2}{|c|}{ Total } & 89482 \\
\hline
\end{tabular}

Analysis on the Changes in land ownership in river conservancy as from 1998-2009

Table 1.1.. Members of the chiredzi river conservancy in the early 1998 
Table 1.2. Members of the chiredzi river conservancy in the 2005 to 2009

\begin{tabular}{|c|c|c|c|c|c|}
\hline Ranch & Owner & $\begin{array}{c}\text { Newly } \\
\text { resettled }\end{array}$ & Area(hectare) & $\begin{array}{c}\text { Area } \\
\text { occupied }\end{array}$ & $\begin{array}{c}\text { Area } \\
\text { unoccupied }\end{array}$ \\
\hline Spear grass & C.Holden & 24 & 1808 & 1808 & 0 \\
\hline Nyamadingidza & C.Holden & 35 & 1866 & 1866 & 0 \\
\hline Melrose & A Davies and D.Nesbit & 55 & 1816 & 1816 & 0 \\
\hline Glen-devon & G. Southwood & 112 & 1825 & 1825 & 0 \\
\hline Dawlish & D.Nesbit & 125 & 5678 & 5678 & 0 \\
\hline Sebanani & B.Van Aarde & 75 & 3655 & 3655 & 0 \\
\hline Oscro & T. Sarpo & - & 3010 & 0 & 3010 \\
\hline Chiredzi ranch south lot 2 & I Rukatya(leased by & - & 5104 & 0 & 5104 \\
\hline Mungwezi & T.Sarpo) Balance & 160 & 5038 & 3938 & 1100 \\
\hline Crown ranch east & $\begin{array}{c}\text { Hein family(leased by } \\
\text { Dombodema ranching) }\end{array}$ & 170 & 9307 & 6765 & 2542 \\
\hline Buffalo range & Style family & 300 & 17000 & 13000 & 4000 \\
\hline Ruware & Ade la Rue & 2000 & 33375 & 27375 & 6000 \\
\hline Total & 12 & 3056 & 89482 & 67726 & 21756 \\
\hline
\end{tabular}

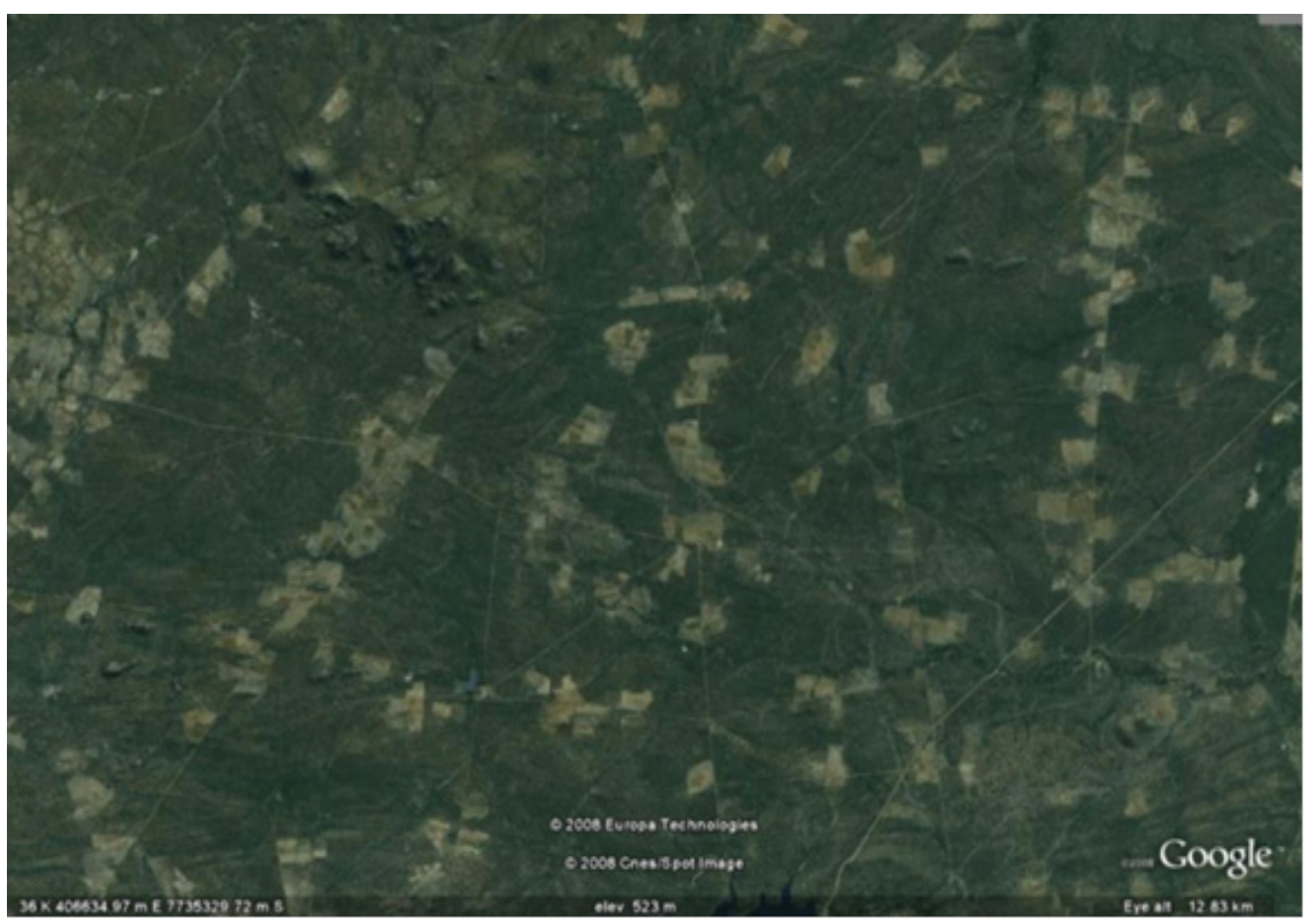

In 1998 chiredzi conservancy was owned by 11 whites and only one black family. However in 2009 and as a result of the fast track land reform and resettlement programme the conservancy became significantly fragmentated among 3056 blacks and 5 white families but whose hacterage was heavily reduced. 
Table 4.1. changes in population distribution and feeding habits of Roan Antelope in the conservancy(source: secondary and primary data).

\begin{tabular}{|c|c|c|c|}
\hline Observed items & Pre 2000 Results(averages) & Post2000 Results(averages) & $\begin{array}{l}\text { Percentage change } \\
(\%)\end{array}$ \\
\hline Herd size & 10 individuals & 4 individuals & 60 \\
\hline Bulls per herd & 1 & $0-1$ bulls & - \\
\hline $\begin{array}{c}\text { Range size } \\
\text { grazed per year }\end{array}$ & 8400 hectares & 600 hectares & 92 \\
\hline $\begin{array}{c}\text { Preferable } \\
\text { grazing area }\end{array}$ & $\begin{array}{c}\text { Grazing area with grass with average } \\
\text { height } 1.5 \text { meters }\end{array}$ & $\begin{array}{c}\text { Grazing area with grass with height as } \\
\text { below as } 20 \mathrm{~mm}\end{array}$ & - \\
\hline $\begin{array}{l}\text { Preferable } \\
\text { grazing time of } \\
\text { the day }\end{array}$ & Early in the morning and late afternoon & Throughout the day & - \\
\hline $\begin{array}{l}\text { Preferable grass } \\
\text { species }\end{array}$ & $\begin{array}{c}\text { aristida, } \\
\text { dactyloctenium,panicum,brachiaria and } \\
\text { digitaria }\end{array}$ & $\begin{array}{l}\text { aristida, } \\
\text { dactyloctenium,panicum,brachiaria } \\
\text { and digitaria } \\
\end{array}$ & \\
\hline $\begin{array}{l}\text { Frequency of the } \\
\text { species get to } \\
\text { drinking water }\end{array}$ & Three times a day & Once a day & 60 \\
\hline $\begin{array}{l}\text { Frequency of } \\
\text { lactating mother } \\
\text { attend their } \\
\text { offspring }\end{array}$ & $\begin{array}{c}6 \text { times a day early stage offspring } \\
\text { development }\end{array}$ & 4 times a day & 30 \\
\hline $\begin{array}{l}\text { Frequency of } \\
\text { visiting the salt } \\
\text { pans }\end{array}$ & Late afternoon 1500 hours & Occasionally observed on the salt pans & - \\
\hline $\begin{array}{c}\text { Preferable } \\
\text { browse tree } \\
\text { species }\end{array}$ & $\begin{array}{l}\text { compretum Mopani, strychnos ssp, and } \\
\text { acacia }\end{array}$ & $\begin{array}{l}\text { compretum Mopani, strychnos ssp, } \\
\text { and acacia }\end{array}$ & - \\
\hline $\begin{array}{l}\text { Effective grazing } \\
\text { hours }\end{array}$ & 6 hours & 8hour & 122 \\
\hline Browse line limit & $1500 \mathrm{~mm}$ & $1200 \mathrm{~mm}$ & 20 \\
\hline
\end{tabular}

\section{Analyses on the effects in changes of population distribution and feeding habits of roan antelope 1998 -2009 in chiredzi river conservancy}

Results from field measurements for physiological characteristics of a Roan Antelope.

Table 4.2. Data on height, weight, horn size and dental characteristics of four Roan Antelope in Chiredzi River Conservancy (primary data)

\begin{tabular}{|c|c|c|c|c|c|}
\hline \multicolumn{6}{|l|}{$15^{\text {th }}$ of December 2009} \\
\hline $\begin{array}{l}\text { Species description } \\
\text { (coding) }\end{array}$ & Height $(\mathrm{cm})$ & Weight(kg) & Horn size(mm) & BMR(kj) & $\begin{array}{c}\text { Average Dental } \\
\text { characteristics }\end{array}$ \\
\hline H/S 001 & 105 & 65 & 40 & $65\left(70^{3 / 4}\right)$ & $\mathrm{M}$ \\
\hline $\mathrm{H} / \mathrm{S} 002$ & 112 & 55 & 97 & $55\left(70^{3 / 4}\right)$ & M \\
\hline $\mathrm{H} / \mathrm{S} 003$ & 135 & 197.7 & 120 & $197.7\left(70^{3 / 4}\right)$ & $\mathrm{Pe}$ \\
\hline $\mathrm{H} / \mathrm{S} 017$ & 136 & 235 & 150 & $235\left(70^{3 / 4}\right)$ & $\mathrm{P}$ \\
\hline Average totals & $\underline{122}$ & $\underline{138.2}$ & $\underline{101.7}$ & $138.2\left(70^{3 / 4}\right)$ & $\underline{\mathrm{Mp}}$ \\
\hline \multicolumn{6}{|l|}{$15^{\text {th }}$ of March 2010} \\
\hline $\begin{array}{c}\text { Species } \\
\text { description(coding) } \\
\end{array}$ & Height $(\mathrm{cm})$ & Weight(kg) & Horn size(mm) & $\operatorname{BMR}(\mathrm{kj})$ & $\begin{array}{l}\text { Average dental } \\
\text { characteristics }\end{array}$ \\
\hline $\mathrm{H} / \mathrm{S} 001$ & 108 & 70.45 & 100 & $70.45\left(70^{3 / 4}\right)$ & $\mathrm{Pe}$ \\
\hline $\mathrm{H} / \mathrm{S} 002$ & - & - & - & - & - \\
\hline $\mathrm{H} / \mathrm{S} 003$ & 136 & 188.65 & 121 & $198.65\left(70^{3 / 4}\right)$ & $\mathrm{Pe}$ \\
\hline $\mathrm{H} / \mathrm{S} 017$ & 136.7 & 212 & 150 & $237.8\left(70^{3 / 4}\right)$ & $\mathrm{P}$ \\
\hline Average totals & $\underline{95.28}$ & $\underline{117.8}$ & $\underline{92}$ & $117.8\left(70^{3 / 4}\right)$ & $\underline{\mathrm{Pe}}$ \\
\hline Percentage $(\%)$ change & $\underline{21.9}$ & $\underline{14.8}$ & $\underline{9.5}$ & $\underline{14.6}$ & $25 \%$ \\
\hline
\end{tabular}


Results from skull examination of Roan Antelope from 1998 to 2009

Table 4.3. Results of skull examination of roan antelope in the Chiredzi river conservancy 1998 to 2009(primary data).

\begin{tabular}{|c|c|}
\hline Species skull description(coding) & Average dental characteristics \\
\hline SH/S 001 & $\mathrm{Pe}$ \\
\hline $\mathrm{SH} / \mathrm{S} 002$ & $\mathrm{~m}$ \\
\hline $\mathrm{SH} / \mathrm{S} 003$ & $\mathrm{Pe}$ \\
\hline $\mathrm{SH} / \mathrm{S} 017$ & $\mathrm{P}$ \\
\hline Average totals & $\underline{\mid c}$ \\
\hline Percentage (\%)change & 18.6 \\
\hline
\end{tabular}

Where $\quad \mathbf{P e}$-permanent teeth at eruption stage

$\mathbf{M}-$ milk teeth (deciduous teeth)

$\mathbf{P}$-permanent teeth

Results on demographic characteristics of a Roan Antelope basing on information obtained as from (1998- 2010).

Table 4.3. Demographic characteristics of the roan antelope in Chiredzi River Conservancy (1998-2009)(secondary and primary data).

\begin{tabular}{|c|c|c|c|c|c|}
\hline Period in years & Total Population & $\begin{array}{c}\text { Population } \\
\text { viability }\end{array}$ & $\begin{array}{c}\text { \% change in } \\
\text { population }\end{array}$ & $\begin{array}{c}\text { Rephus } \\
\text { reproductive } \\
\text { rate }\end{array}$ & $\begin{array}{c}\text { Population } \\
\text { Growth rate }\end{array}$ \\
\hline 1998 & 20 & 0 & 0 & 1 & 1.43 \\
\hline 2000 & 30 & 0.1 & 50 & 1.02 & 1.43 \\
\hline 2003 & 20 & -0.1 & 33 & 1.2 & 1.2 \\
\hline 2005 & 16 & -0.07 & 20 & 1.89 & 0.9 \\
\hline 2008 & 12 & -0.09 & 25 & 2.67 & 0.57 \\
\hline $2010 @ 15$ March 2010 & 5 & -0.3 & 50 & 3.5 & 0.01 \\
\hline
\end{tabular}

Total population trends and population growth rate of Roan Antelope as from 1998 to 2009.

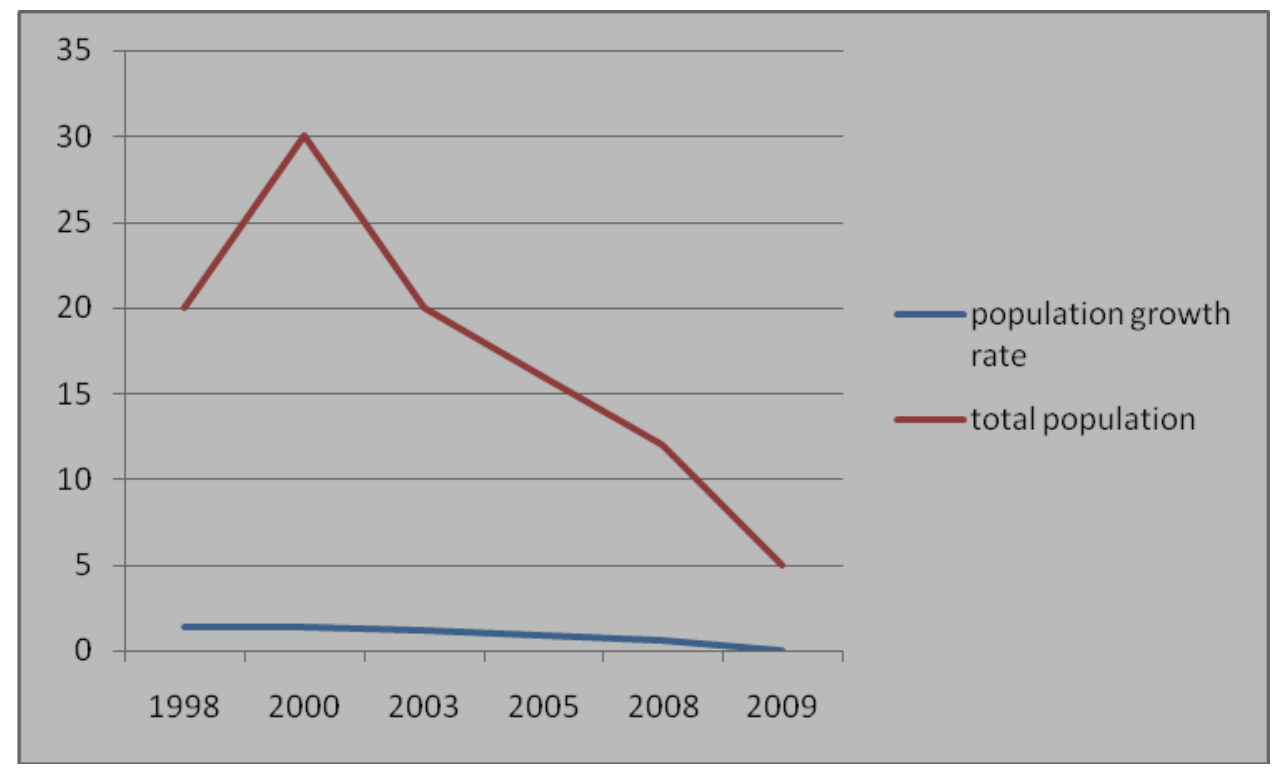

years

Trends in Population viability and rephus reproductive in Roan Antelope as from( 1998-2009) 
102 The Impact of Conservancy Fragmentation on the Population Distribution and Feeding Patterns of Roan Antelope 2000-2009: The Case of Chiredzi River Conservancy

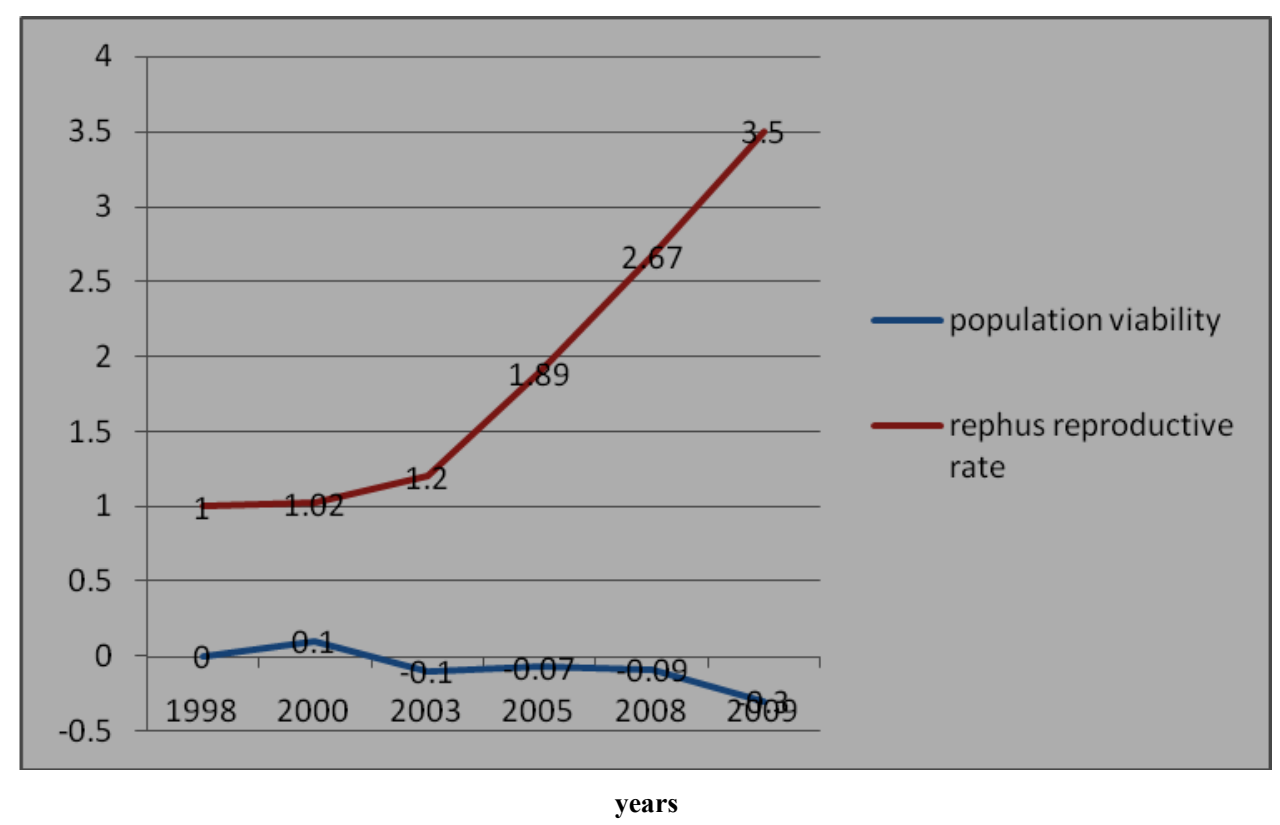

Figure 4.2. Trends in population viability and rephus reproduction(birth interval)

\section{Relationship between mortality rate and reproduction}

Table 4.4. Mortality rate and reproduction as from (1998-2009)(secondary and primary data)

\begin{tabular}{|c|c|c|c|c|}
\hline YEARS & MORTALITY RATE & \% change & REPRODUCTIVE RATE & \% change \\
\hline 2000 & 1.01 & 0 & 3.9 & 0 \\
\hline 2003 & 1.09 & 7.9 & 3.7 & -2.6 \\
\hline 2005 & 2.9 & 166 & 1.2 & -67.6 \\
\hline 2007 & 3.5 & 20.7 & 0.09 & -92.5 \\
\hline 2009 & 3.8 & 8.6 & 0.01 & -88.8 \\
\hline
\end{tabular}

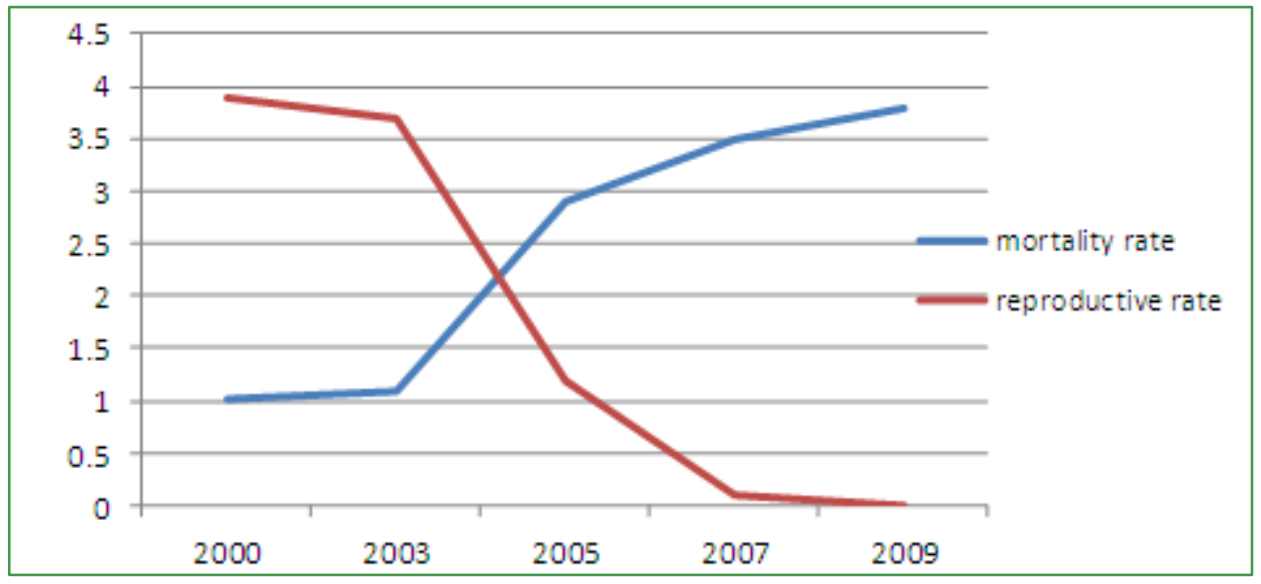

Years

Figure 4.3. the relationship between mortality rate and reproduction as from (1998-2009), source: (primary data)

Life expectancy of the Roan antelope across all age groups as from (1998 -2009) 


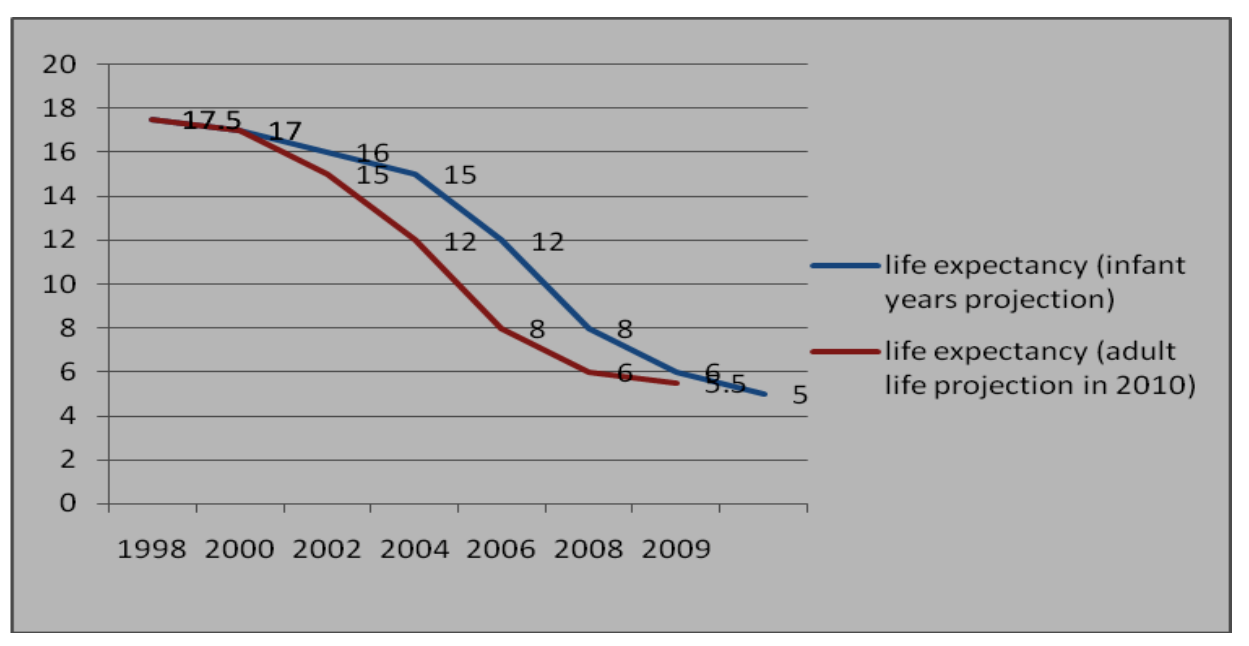

Years

Figure 4.4. Comparative life expectancy between infant and adults as from (1998-2009),

\section{Results on hay analysis of three different grass species in the conservancy.}

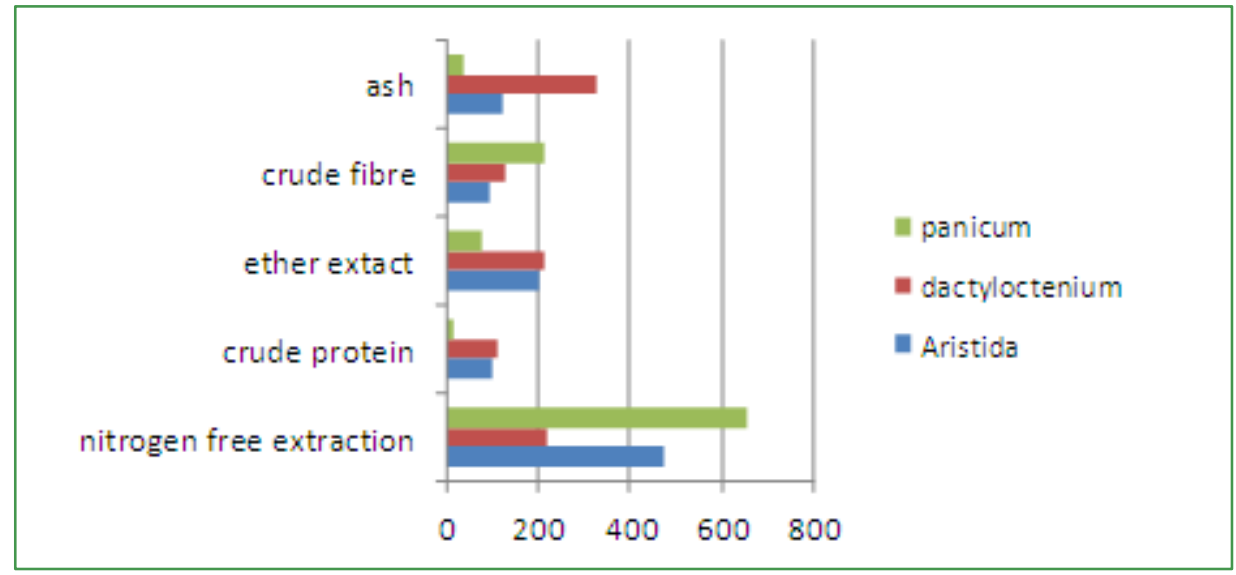

Nutritional value in $\mathbf{g} / \mathrm{kg} 1$

Figure 4.5. The nutritional content of the three different grass species (primary data)

From the readily available grass species in the conservancy the above three grass specie are the most common. The researcher observed that among them, panicum is the mostly dominant species followed by dactyloctenium and aristida. Meanwhile among them in terms of total Nitrogen free extraction (N F E) content test results show that aristida had the highest content. From analysis of the results from experimental examination of feed sample of $1000 \mathrm{~g}$, aristida constitutes $668 \mathrm{~g} / \mathrm{kg}$. However the aristida has poor protein content that is less than $150 \mathrm{~g} / \mathrm{kg}$ of feeding sample. Research findings show that the state of forage in the conservancy is relatively poor. It significantly contributed to the fall of total average BMR by $14.6 \%$ among the Roan Antelope species. In addition from experimental analysis there is need to add some antibiotics when mixing small amounts with the feed which will alter the microbial population of the rumen and intestine, resulting in improved growth and feed efficiency and also adding certain chemicals and hormones that stimulate growth by altering chemical reactions in the body. The graph shows that panicum is currently the highly nutritious grass species found in the conservancy. From observation the state of the panicum grass species is in poor condition due to heavy grazing from all grazers such as buffaloes, cattle, zebras and other small grazers.

\section{Results from statistical analysis of related variables tested}

From experimental analysis of the results in this research the forage quality directly controls the rephus (birth interval) in Roan Antelope. The correlation coefficient was tested using the Pearson's product moment and the result obtained was 0.9786 . This shows that the forage quality is directly related to and controls the birth interval (rephus). The results analysis explaining that forage quality significantly controls estrus in wildlife (Kumar et al 2004). The statistical test also revealed that BMR is strongly linked to the physiological characteristics of the Roan Antelope. This shows that BMR is a function of physiological characteristics of a species. 


\section{Evaluation of conservation and management strategies applied in the conservancy.}

One of the ranch manager in Wasara Wasara ranch stated that at the present moment there are several management and conservation strategies that were being practised and implemented in the conservancy. These strategies include the use of laws and regulations, awareness campaigns (community out reach), engaging in community projects, and introduction of protected area systems (I.P.Z), Restocking and Translocation.

The environmentalists highlighted that among six strategies they employed in the conservancy management, two of them came out with meaningful results. Community out reach and engaging in community project development were the two strategies that helped the local community to realise that through conservation of natural resources, there are long term benefits. He further castigated that a total of 600 villages out of 1500 villages resettled in the conservancy were reached every year as from 2004 to date. However he pointed out that the total number of people reached was not enough as compared to the magnitude of the impact imposed due to fast track land reform to wildlife.

Meanwhile, since translocation was a better motive in the management of Roan Antelope, financial constraints remained a major draw back as stated by the Ranch Manager. He pointed out that the only way to do away with drastic decline in wildlife specie thus to move out the species to safer destination such as in Chipinda Pools which $259 \mathrm{~km}$ south of the conservancy which was not affected by 2000 fast track land reform programme.

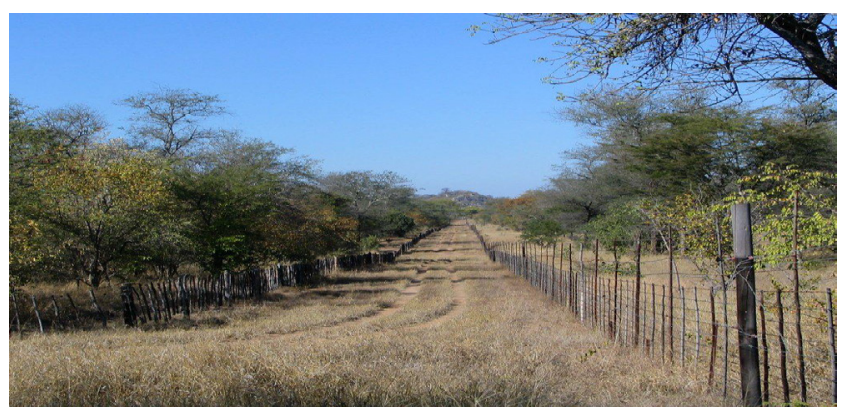

chipinda in gonarenzou national park picture taken in 2007 by Munzanza Dickson

One of the chief Ecologists operating in the conservancy stated that the only option left that can save the remaining population in the conservancy is thus to create intensive protected zones in the area and later release the population in natural nature only when the population is viable. He further pointed out that efforts were being made but the remaining challenge remains lack of financial and moral support from the government. Even though the area was allocated it is too small to accommodate full and free ranching area of roan antelope because the species require an area of more than 10 000 hectares per year for grazing only while the area allocated tally to 6000 hectares.

The parks and wildlife warden officer in the conservancy highlighted that though there were sign of good 1 effort done but there are still a lot to be done since the conservancy management board did not have performance bottom line and were not kept accountable for the day to day transactions. He added that among the laws and legislation put forward nothing of them was found working in the conservancy since poachers were not dealt with accordily. He stated that most cases of poaching rose were ending up politised.

One of the respondents in the conservancy stated that the government and other interested organisation have to chip in and facilitating immediate re arrangement of resettlements to those already resettled. He further highlighted that this will help in the re-demarcation of the conservancy which will act as a panacea to the prevailing problems than trying restocking and translocation of specie where he concluded as waste of time and resources.

From the observation the researcher concluded that from all management practises being implemented in the conservancy were worth full only when the government clearly re-arrange the farmers according to resource bases as well as capability.

\section{Conclusions and Recommendation}

\section{Conclusions}

The research findings concluded that violation of wildlife rights was seriously committed in the conservancy as a result of 2000 fast track land reform programme. Habitat compression significantly affected the feeding patterns of Roan Antelope. The research revealed that lack of required nutritional elements in feed sample imposed negative impacts to the general Roan antelope physiological characteristics especially it slows body growth, delayed teeth eruption and significantly affecting estrus in female. The findings concluded that Roan Antelope is facing extinction in the Chiredzi river conservancy. The research find some recommendations that works in safe guarding the rapid extinction of the species such as the translocation and introduction of intensive protected zones(I .T .Z).However the research pointed out that financial constrains and political instability prevailing in Zimbabwe hindering the implementation of all these management strategies.

\section{Recommendations}

- The government has to bring the fast track land reform programme to finality by regularizing resettlement in the Chiredzi river conservancy. This will save wildlife from rampant poaching and from further unnecessary encroachment of agricultural activities.

- There is need for creation of intensive protected zones (I.P.Z) in the conservancy so as to uphold the population of the species in the area, more so the department of parks and wildlife has to be part and parcel of the motive.

- The state has to provide social, financial and moral support to the conservancy; by giving wild life 
management an economic, social and environmental comparative advantage. In addition there is need to modify institutions, laws and norms as to translate wildlife comparative advantage into real incentives for landholders to take up conservation as a viable social, economic and biological business.

\section{List of Acronyms}

$\begin{array}{ll}\text { AUM } & \text { Animal unit month } \\ \text { BMR } & \text { Basal metabolic rate } \\ \text { CITES } & \begin{array}{l}\text { Convection on International } \\ \text { Trade in Endangered species }\end{array} \\ \text { CSO } & \text { Central Statistics Office } \\ \text { IUCN } & \text { International Union for the } \\ & \text { Conservation of Nature And } \\ & \text { Natural Resources } \\ \text { M } & \text { Molars } \\ \text { PM } & \text { Premolars } \\ \text { YNPY } & \text { Neuropeptide } \\ \text { UNEP } & \text { United Nations Environment } \\ & \text { Programme }\end{array}$

\section{Appendix}

\section{Appendix A}

Interview Schedule

1. Professional qualification

2. Experience spend in wildlife management industry

3. Which game counting techniques do you practice? What were the herds sizes normally seen in the conservancy pre 2000

4. How many bulls were usually seen on a spotted herd?

5. What was the average ranching area does Roan Antelope herd grazed per day.
6. What was the normal feeding hours of Roan Antelope usually observed for the pre 2000 ?

7. How frequent does a lactation mother attending its offspring per day?

8. What were the preferable grazing areas of the Roan Antelope?

9. List out grass and tree species palatable to Roan Antelope?

10. What was the size of the conservancy under wildlife production in terms percentage area before it was being fragmentated?

11. What is the average lower and upper browse line limit of the Roan Antelope

12. What are the major farming activities being practiced by newly resettled individual farmers in the conservancy?

13. State the total effective grazing hours per day per season of Roan Antelope?

14. State the normal resting hours of a normal grazing Roan Antelope?

15. What are the major problems being faced by Roan Antelopes?

16. What are the management strategies put in place to restore these problems?

17. How effective are these strategies in addressing the problems encountered?

18. What are the challenges being emanating when trying to implement all these management strategies?

19. Please summarize the current status of the conservancy base on observation and information?

20. Please summarise the level of immediate future threat of Roan Antelope in the conservancy?

21. What do you think government or any other interested organization should do to help the wildlife industry?

22. What is the management structure of the conservancy currently looking like?

\section{Appendix B}

Field Patrol Data Sheet

Research Team Leader.

Research Recorder.

Species Under Investigation.

Research Method.

Date. Time. 


\begin{tabular}{|c|c|c|c|c|c|c|}
\hline Grid location(lot \#) & $\operatorname{Sex}(\mathrm{f} / \mathrm{m})$ & Height $(\mathrm{m})$ & Mass(kgs) & Teeth description & BMR & Horns size \\
\hline & & & & & & \\
\hline & & & & & & \\
\hline & & & & & & \\
\hline & & & & & & \\
\hline
\end{tabular}

\section{REFERENCES}

[1] African hunting adventures, (2001), Roan Antelope in the southern Africa www.africanhuntingadventure.org.uk assed on 14 November 2009

[2] Annual Review of Ecology, Evolution and systematic, volume 34 page 487-515 published November (2003)

[3] Bruckhorst DJ, (1999), Bioregional planning resource management beyond the new millennium, Harvard academic publisher UK

[4] Camille.P. (2006), ecological and evolutionary responses to recent climate change, annual review of ecology, evolution and systematic volume 37 page 637-669

[5] Chenje M,Sola,L and Paleczny.D,(2000), the state of Zimbabwe environment, government of the republic Zimbabwe , ministry of mines environment and tourism Harare Zimbabwe.

[6] Chenje, M,,Sola,L and Paleczny.D,(1998), the state of Zimbabwe environment, government of the republic Zimbabwe, ministry of mines environment and tourism Harare Zimbabwe.

[7] Child, (2004), Park in transition: biodiversity, rural development and the bottom line, Earthscan.UK

[8] Chiras D and Reganold J, (2005) Natural Resource Conservation $9^{\text {th }}$ edition prentice hall USA

[9] Derman B, (1990), the Unsettling Of the Zambezi Valley. An examination of the mid Zambezi rural development process, CASS publication centre for applied social science studies, University Of Zimbabwe

[10] Dudley N, Madeley J and Stalton S, (1992) land is life, land reform and sustainable agriculture, intermediate technology publications London WC18 4HH, UK.

[11] Feffery R and Leigh S, (2006), Essay in Animal Behavior .Elgevier Limited USA

[12] Gerald, J, Michael E and McDonald N, (2004), Application of ecological indicators, animal review of ecology, evolution and systematic volume 35 page 89-111

[13] Green ,NP.O, Stout, G.W ,and Taylor D.J, (1998) Biological Science, Organism Energy And Environment $2^{\text {nd }}$ edition, Cambridge University, UK.

[14] IUCN sscAntelope Specialists Group, (2008), IUCN Red List of Threatened Species, IUCN.

[15] Journal of East Africa national history (2008) volume 97 part 1journal of biodiversity. Benny Byte Bier, Nairobi Kenya
[16] Kenmuir and Williams, R, (1974), Wild Animals, Bundy series Longman Zimbabwe

[17] Kumar A and Asyer M, (2004), Biodiversity, Principles and Conservation Agro Bios .Prentice Hal 1 India

[18] Lenore, F, (2009), Effects of habitat fragmentation on Biodiversity, Ottawa-Carleton Institute of Biology Carleton University, Canada

[19] Magadza, C.H.D, (1998), Conservation for preserving the environment. The mambo press Gweru Zimbabwe.

[20] Malilangwe conservation trust, (2008), annual report development through conservation

[21] Malilangwe conservation trust, (2005), annual report development through conservation

[22] Malilangwe conservation trust, (1998), annual report development through conservation

[23] Marwell wildlife, (2009), Roan Antelope in the animal encyclopedia www.marwell.org.uk assed on 24 November 2009

[24] Michael T, (1988), Deep Ecology, San Marcos, California

[25] Morrison M.1, Marcol B, G and Mannan RW (1992), Wildlife Habitat Relationships, Concepts and Application. The University of Wscon press Madison, Unsconsin USA

[26] Moyo S, (2000).land reform under structural adjustment in Zimbabwe land use change in the mashonaland province Elanders Gotad Stockholm Sweden

[27] Nyamapfene, P.L, (1991), The Soils of Zimbabwe. Nehanda publisher limited Harare

[28] Panc, C and Rogers, J, (2009), Development of Wild Land Resources and Ecology Centre, Utah state university Logan Utah USA

[29] Peterson.J.H, (1991), campfire: A Zimbabwean Approach To Sustainable Development Through Wildlife Utilization, Centre Of Applied Social Sciences (CASS), and University Of Zimbabwe

[30] Poiani,K,A, Michael D $M$ and Chapman KA, (2008 ),Identifying Conservation-Priority Areas In A Fragmented Minnesota Landscape Based On The Umbrella Species Concept And Selection Of Large Patches Of Natural Vegetation, Department of natural resources, 16 Fernow Hall Cornel university Ithaca NY 14853,Etats-unis USA

[31] Santiago's and lidon, R (2010), A common currency for the different ways in which patches and links can contribute to habitat availability and connectivity in the landscape, Ecography .Scan Earth.UK

[32] Smither, D, R and Reay, H, N, (1973), Mammals List Of Species Known To In Rhodesia, National museum and 
monuments of Rhodesia

[33] The living worlds of animals, (1970), Readers Digest Association, London UK

[34] Trisha, Swift S, J and Harmon N (2010), Critical Threshold Associated With Habitat Loss: a review of the concepts evidence and application. A Biological Reviews number 85

[35] Tuli, D.S and Hawkins, D.J. (1993), Marketing Research Measurement And Method $6^{\text {th }}$ edition. Macmillan Publishing

\section{Company .USA}

[36] Van Daken, B, (1994), Understanding Scientific Research an Introduction $4^{\text {th }}$ edition, Blackwell.UK

[37] Wildlife Africa, (2009), Wildlife in Context: Roan Antelope in the animal encyclopedia www.wildlifeafrica.org. accessed on 06 November 2009

[38] Whitmore.T.C and Sayer.J.A (1992), Tropical Deforestation and Species Extinction, Chapman and hall, India 